\title{
Role of the JAK-STAT Pathway in Bovine Mastitis and Milk Production
}

\author{
Muhammad Zahoor Khan ${ }^{1}{ }^{10}$, Adnan Khan ${ }^{2}{ }^{\mathbb{D}}$, Jianxin Xiao ${ }^{1}$, Yulin Ma ${ }^{1}$, Jiaying Ma ${ }^{1}$, \\ Jian $\mathrm{Gao}^{3}$ and Zhijun Cao ${ }^{1, * \mathbb{D}}$
}

1 State Key Laboratory of Animal Nutrition, Beijing Engineering Technology Research Center of Raw Milk Quality and Safety Control, College of Animal Science and Technology, China Agricultural University, Beijing 100193, China; zahoorkhattak91@163.com (M.Z.K.); dairyxiao@gmail.com (J.X.); ma18810318038@163.com (Y.M.); majiaying@cau.edu.cn (J.M.)

2 Key Laboratory of Animal Genetics, Breeding, and Reproduction, Ministry of Agriculture \& National Engineering Laboratory for Animal Breeding, College of Animal Science and Technology, China Agricultural University, Beijing 100193, China; dr.adnan93@cau.edu.cn

3 Department of Clinical Veterinary Medicine, College of Veterinary Medicine, China Agricultural University, Beijing 100193, China; gaojian2016@cau.edu.cn

* Correspondence: caozhijun@cau.edu.cn; Tel.: +86-10-62733746

Received: 23 September 2020; Accepted: 5 November 2020; Published: 13 November 2020

Simple Summary: The cytokine-activated Janus kinase (JAK) —signal transducer and activator of transcription (STAT) pathway has an important role in the regulation of immunity and inflammation. In addition, the signaling of this pathway has been reported to be associated with mammary gland development and milk production. Because of such important functions, the JAK-STAT pathway has been widely targeted in both human and animal diseases as a therapeutic agent. Recently, the JAK2, STATs, and inhibitors of the JAK-STAT pathway, especially cytokine signaling suppressors (SOCSs), have been reported to be associated with milk production and mastitis-resistance phenotypic traits in dairy cattle. Thus, in the current review, we attempt to overview the development of the JAK-STAT pathway role in bovine mastitis and milk production.

Abstract: The cytokine-activated Janus kinase (JAK) - signal transducer and activator of transcription (STAT) pathway is a sequence of communications between proteins in a cell, and it is associated with various processes such as cell division, apoptosis, mammary gland development, lactation, anti-inflammation, and immunity. The pathway is involved in transferring information from receptors on the cell surface to the cell nucleus, resulting in the regulation of genes through transcription. The Janus kinase 2 (JAK2), signal transducer and activator of transcription A and B (STAT5 A \& B), STAT1, and cytokine signaling suppressor 3 (SOCS3) are the key members of the JAK-STAT pathway. Interestingly, prolactin (Prl) also uses the JAK-STAT pathway to regulate milk production traits in dairy cattle. The activation of JAK2 and STATs genes has a critical role in milk production and mastitis resistance. The upregulation of SOCS3 in bovine mammary epithelial cells inhibits the activation of JAK2 and STATs genes, which promotes mastitis development and reduces the lactational performance of dairy cattle. In the current review, we highlight the recent development in the knowledge of JAK-STAT, which will enhance our ability to devise therapeutic strategies for bovine mastitis control. Furthermore, the review also explores the role of the JAK-STAT pathway in the regulation of milk production in dairy cattle.

Keywords: bovine mastitis; JAK-STAT pathway; JAK2; STATs; SOCS3; immunity; milk production 


\section{Introduction}

Bovine mastitis is a seriously infectious and contagious disease, which is a massive threat to the dairy industry throughout the globe [1]. Mastitis is the inflammation of the mammary gland, which is characterized by physical, chemical, and microbiological alterations in milk, following pathological changes in udder tissue [2]. Bovine mastitis is described as acute or chronic based on inflammation, redness, and localized heat at the infected area, with more severe symptoms, such as fever, leading to septicemia, and the formation of abscesses [3,4]. There are two types of mastitis: clinical and subclinical mastitis. In most cases, infection with Gram-negative bacteria such as Escherichia coli (E. coli) can often cause clinical mastitis, and Gram-positive bacteria such as Staphylococcus aureus (S. aureus) are involved in subclinical mastitis infection $[5,6]$.

Bovine mastitis is considered one of the costly diseases of dairy cattle because of milk losses, treatment costs, and rare death [7,8]. In China, the annual losses of 15-45 billion Chinese Yuan (CNY) have been documented [7], while in the US and India, the dairy industry has experienced losses of 2 billion and 526 million dollars, respectively [9]. In Europe, collectively, the cost due to mastitis has reached 1.55 billion euros per year [10]. This increased frequency was linked to public concerns for animal welfare and has made mastitis the key disease of the dairy sector [11]. In addition, bovine mastitis has a major zoonotic risk, correlated with the shedding of bacteria and their toxins into milk [12].

Mammary epithelial cells are the first line of defense of the mammary gland to invading bacteria. They not only act as physical barriers but also are capable of producing inflammatory mediators. While interacting with invading bacteria, mammary epithelial cells generate multiple inflammatory cytokines $[13,14]$. Several genes and pathways have been reported to be associated with the regulation of bovine mastitis [15]. It is well known that the innate immune system recognizes the presence of pathogens ligands through a membrane receptor family known as Toll-like receptors (TLRs) [16]. TLRs are pattern recognition receptors (PRRs) on the host cell surface that recognize bacterial-pathogen-associated molecular patterns [17]. Upon activation, TLRs further mediate different important signaling, such as that of the JAK-STAT pathway.

Any disruption in the JAK-STAT pathway may lead to various diseases, including bovine mastitis that compromises the immune system of the host. Furthermore, it has also been documented that STAT5A works as a mediator for extracellular prolactin receptors. At the same time, JAK2 plays a role as a bridge between STAT5A and prolactin receptor (PrlR), which is essential for milk production and mammary gland development. Keeping in view the vital role of JAK-STAT signaling in immunity, inflammation, and milk production, the current review paper is designed with aims to summarize the role of the JAK-STAT pathway in bovine mastitis and milk production.

\section{General Mechanism of the JAK-STAT Pathway Regulation}

There are three main components of the JAK-STAT pathway: receptors, Janus kinases (JAKs), signal transducers, and activators of transcription proteins (STATs) [18]. The mammalian JAK family consists of JAK1, JAK2, JAK3, and tyrosine kinase 2 (TYK2), which are linked to the cytoplasmic domains of diverse cytokine receptors [19]. Among the seven members of STATs (STAT1-4, 5a, $5 \mathrm{~b}$, and 6) in mammalian cells, STAT5A and STAT5B show high sequence identity and lie closest in a head-to-head pattern next to STAT3 $[19,20]$. The members of the STAT family are involved in cell growth, differentiation, cell survival and apoptosis, and mammary gland development. The cytokines, after attachment with receptors on the cell surface, activate JAKs. The two JAKs come close through receptor oligomerization. Furthermore, these JAKs phosphorylate the receptor complex's intracellular tyrosines, generating the docking sites for STATs. Consequently, the activated STATs form hetero- or homodimers, where the Src-homology 2 (SH2) domain of each STAT binds the phosphorylated tyrosine of the opposite STAT, and the dimers then translocate to the cell nucleus to induce transcription of the target genes. JAK-STAT has been revealed to operate downstream of several peptide hormones and cytokines that are necessary for the development of the postnatal and secretory 
function of the mammary gland [21]. The phosphorylated STAT5A and STAT5B form homodimers and heterodimers in mammary epithelial cells in order to regulate the process of differentiation, survival, and proliferation through the modification in cellular gene expression [22]. The rapamycin target phosphatidylinositol 3-kinase-protein kinase B/mammalian signaling pathway (PI3K-Akt/mTOR) mediates many cellular processes such as cell proliferation, growth, survival, and metastasis [23], and it is necessary for the development of the mammary gland [24]. A conditional knockout of Akt1 prevents the extensive survival of mammary epithelial cells, which express hyperactive STAT5, indicating that the PI3K-Akt/mTOR pathway is a crucial downstream signaling effector of JAK-STAT signaling [25]. To find out the interconnection between different genes and their biological functions in the JAK-STAT pathway, we exploited an online software database for annotation, visualization, and integrated discovery (DAVID; https://david.ncifcrf.gov/) [26], which are summarized in Figure 1.

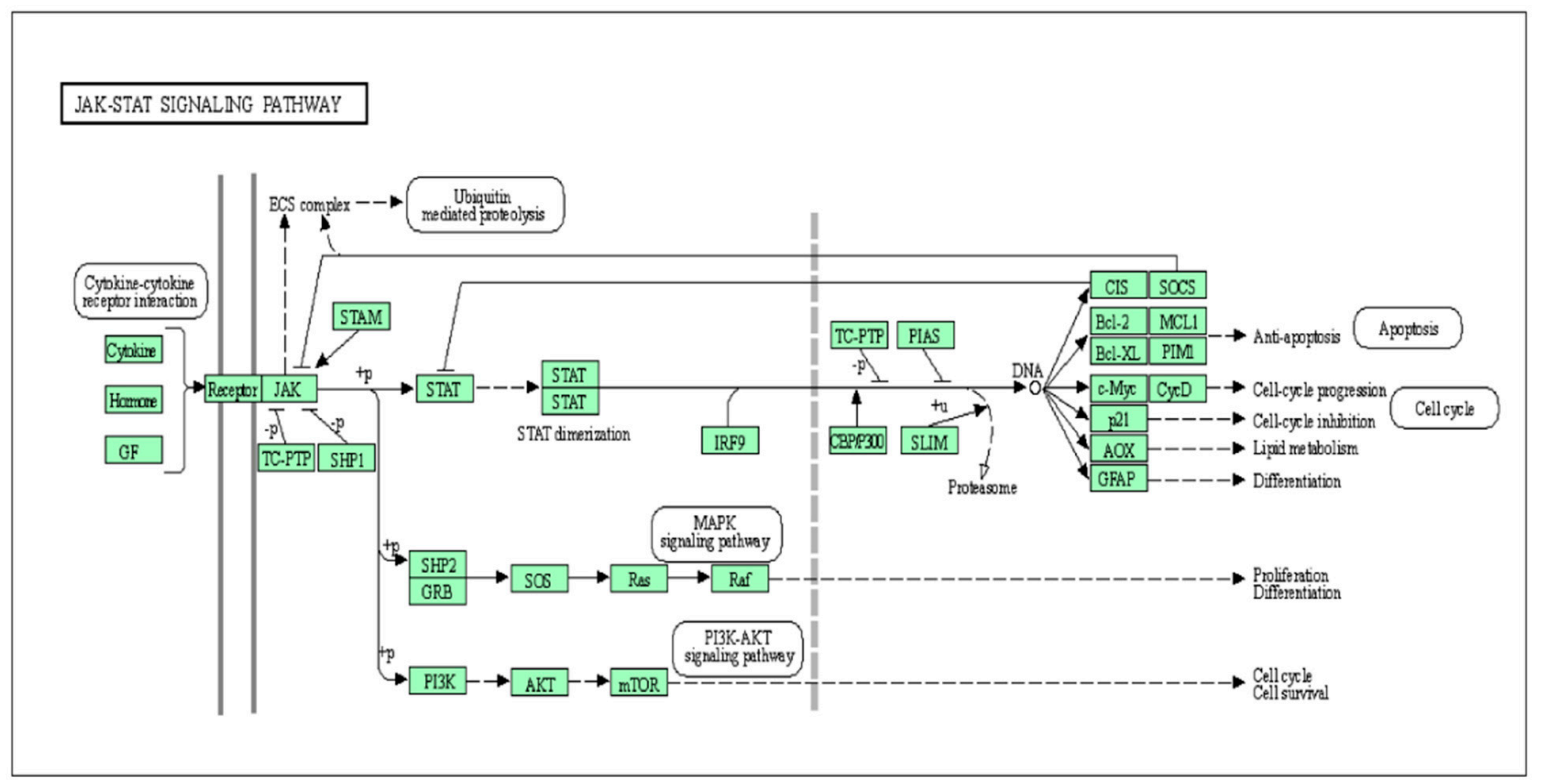

Figure 1. The regulation of the cytokine-activated Janus kinase (JAK)-signal transducer and activator of transcription (STAT) pathway by cytokines, hormones, and growth factors; engagement of the JAK-STAT pathway in the process of differentiation, survival, and proliferation through the modification in cellular gene expression.

STAT5, being the main gene of the JAK-STAT inflammatory signaling pathway, has an essential role in prolactin-induced mammary gland factor and is assumed to be associated with mammary gland development in transgenic mice [27]. Consequently, upon activation, JAK regulates the cellular mechanisms such as cell migration, apoptosis, cell proliferation, and differentiation, which are essential for hematopoietic responses, immune development, mammary gland development, and the lactation process [28]. Cytokines play a vital role in the regulation of the JAK-STAT pathway, which further facilitates immunity and inflammation. Consequently, the JAK-STAT pathway has been widely studied for its critical role in immunity and inflammation [29,30], and evidence indicates that persistent activation of this pathway might lead to many immune- and inflammatory-related diseases [31,32]. Performing a critical role in immunity, cell proliferation, cell differentiation, and inflammation, the JAK-STAT pathway has been widely targeted for therapeutic purposes in several inflammatory diseases [33].

\section{The JAK-STAT Pathway Role in Milk Production in Dairy Cattle}

The JAK-STAT pathway regulates lactation [34], while PI3K/Akt within the JAK-STAT pathway shows overexpression in lactating cows [35]. Gene deletion analysis in mice has documented an important role of the JAK-STAT signaling pathway in the lactation and development of the mammary 
gland $[36,37]$. In the mammary gland, the JAK-STAT pathway, along with SOCS signaling, plays a critical role in controlling cytokine signals and has shown an association with mammary gland development and milk production [38]. Moreover, studies have documented the essential role of the JAK-STAT pathway in blood cell differentiation and casein gene regulation during milk production $[39,40]$. It has been shown that some JAK-STAT-associated proteins are regulated by PrlR, which may establish a balance between growth hormone and milk protein yield [41]. It has been illustrated that by using the JAK-STAT pathway, the lactogenic hormones, through their receptors on cell membranes, regulate milk proteins [42]. Prolactin also uses JAK-STAT signaling and regulates the processes of lactation and reproduction in mammals [43]. It has been documented that a higher concentration of $\mathrm{Prl}$ in blood circulation is associated with an increased level of milk production in dairy cattle [44]. During hypothyroidism, a severe decrease in milk production has been documented. Furthermore, it has been found that hypothyroidism decreases the level of prolactin, resulting in lower expression of the JAK-STAT pathway, which is responsible for lower milk production in hypothyroidized rats [45].

\subsection{Role of JAKs in Milk Production in Dairy Cattle}

JAK2 is the tyrosine kinase responsible for phosphorylation of both PrlR and Stat5, based on tissue culture cell studies. According to one report, in the absence of the JAK2 gene, mammary epithelium proliferation and differentiation were reduced by $95 \%$ around parturition [46]. The endocrine factor prolactin attaches to the PrlRs and causes their dimerization. JAK protein kinases are linked to these receptors and these JAK proteins alter a receptor into a tyrosine kinase receptor. The regulated receptors may specifically phosphorylate inactive STATs, which result in dimerization. These dimers are further translocated into the nucleus. The STATs attach to the upstream promoter elements of the casein gene and cause their transcription. Growth hormones (GHs) control the growth and development of the mammary gland and regulate milk production and milk protein levels in cattle [41,47]. STAT5 passes on messages from cytokines and growth factors outside the cell to the nucleus of the mammary gland epithelial cells and thereby mediates the transcription of the gene during pregnancy, lactation, and weaning [48].

It has been consistently reported that the polymorphisms T-C39652459 and T-C39645396, at intron 15 and exon 20, respectively, in the JAK2 gene, are significantly associated with milk lactose production in dairy cows [49]. Furthermore, the variant $J A K 2 / R s a I$ is involved in the regulation of milk and milk protein and can be considered a milk production marker in dairy cattle [50]. The variants 39630048C/T and 39631175T/C in the JAK2 gene significantly influence milk fat and milk proteins, respectively, in Chinese Holsteins [51]. PrlR uses STAT5A and JAK2 as mediators to activate the proteins associated with milk production traits [52].

\subsection{Role of STATs in Milk Production in Dairy Cattle}

STATs are activated by specific ligands, i.e., STAT5A is regulated by Prl, while STAT5B regulation is mediated through growth hormones (GHs) [53]. STAT5 is an important intracellular mediator of prolactin signaling and can activate transcription of milk proteins in response to Prl. STAT5 has been suggested to be candidate marker genes for milk protein yield and composition in dairy cattle [54]. During pregnancy, STAT5A and PrlR play essential roles in mammary epithelium proliferation and differentiation $[55,56]$. Consequently, it has been found that PrlR has a positive impact on lactation performance in cows, possibly due to its involvement in steroid synthesis and cholesterol regulation [57]. During pregnancy and lactation, STAT5A and STAT5B are the essential proteins required for the synthesis of luminal progenitor cells from mammary stem cells and the differentiation of milk-producing alveolar cells [58]. STAT5A and STAT5B have been linked with the development of the mammary gland during pregnancy [59]. It was previously found that STATs promote the mammary gland cells' survival by mediating the promoters of genes essential for milk proteins $[34,60]$. STATs facilitate various peptide hormones and cytokines in targeted cells such as Prl and GH and are linked to milk production. Whey acidic protein (WAP) is expressed in the mammary gland and is associated with 
the improvement of milk protein. STAT5 has been considered an important transcription factor that is responsible for the regulations of Prl at $5^{\prime}$ flanking regions of WAP [61]. It has been observed that the downregulation of Prl in hypothyroidized rats causes the inhibition of the transcriptional activity of STAT5. Consequently, any abnormality in the thyroid gland severely affects milk production efficiency in rats because of the low level of Prl [45]. In addition, GH also regulates the STAT1 gene and its expression has been reported during mammary gland development [62,63]. Furthermore, a study has reported the combination effect of STAT1 with other JAK-STAT signaling members on milk production traits [38]. Keeping in view the important role of STATs as a mediator of prolactin signaling, the polymorphisms in these genes were further studied for its role in milk production.

The mutations in the STAT5A gene have been reported for their effect on milk yield [64]. Consistently, the STAT5A/AvaI polymorphism at position C-T 6853/exon7 was documented to be associated with milk production and could be used as a significant marker for milk improvement [65]. In addition, the STAT5A/MslI locus has been found to be correlated with milk yield, milk fat, and protein [65-67]. The polymorphic site A14217G and 17266indelCCT in STAT5A have shown significant associations with milk protein percentage and milk yield, respectively [68]. Consequently, Schennink et al. documented that single nucleotide polymorphism (SNP) 9501G>A in STAT5A significantly influenced milk fat composition [69]. Khatib et al. noticed that variant $12195 \mathrm{~T} / \mathrm{C}$ in STAT5A was significantly linked to a decrease in milk fat and protein percentage in dairy cattle [70]. The variant $31562 \mathrm{~T}>\mathrm{C}$ in STAT5B was reported to be associated with milk yield and milk protein [71]. The association of CD4 and STAT5B with milk traits might be due to their role in the regulation of prolactin-induced mammary gland factor [72]. Moreover, the variant in the STAT 1 gene has been documented to be linked with milk fat, milk protein, and milk yield in dairy cattle [73]. Consequently, the polymorphism STAT1/BspHI has been reported to be associated with milk production traits in Jersey cows [74]. Similarly, Deng et al. reported that SNPs in STAT1 have a significant association with milk production traits and could be a useful addition to the marker-assisted selection for milk production [75].

The above findings reveal that the JAK-STAT pathway plays a central role in the regulation of milk production traits.

\section{The JAK-STAT Signaling Role in Bovine Mastitis}

As mastitis is an immunity- and inflammatory-related disease, scientists have widely targeted the JAK-STAT pathway in bovine mastitis control research. Besides having a critical role in mammary gland development, any abnormal regulation may disturb the normal function of the JAK-STAT pathway, resulting in impairment of mammary gland development and exposure to mammary infections. Buitenhuis et al. found the altered expression of the JAK-STAT pathway in the mammary gland tissue of cows challenged with E. coli [76]. It is well known that the JAK-STAT pathway is regulated by IFN, LPS, or growth factors. In its turn, JAK-STAT signaling mediates proinflammatory cytokines. Tiezzi et al. documented the JAK-STAT pathway as a key pathway that regulates clinical mastitis [77]. Recently, it has been reported that cirsimarin (an extract of Cirsium japonicum var. ussuriense) treatment suppressed the expression of inflammatory cytokines by downregulating the phosphorylation of the JAK-STAT pathway in the mammary gland. Thus, this substance can be targeted as a therapeutic agent in many inflammatory diseases, including bovine mastitis [78]. It has been shown that 8-methoxypsoralen treatment protects bovine mammary epithelial cells against lipopolysaccharide-induced inflammatory injury by inhibition of the JAK/STAT and NF-kB pathways [79]. JAK-STAT suppression by xanthotoxin resulted in the downregulation of IL-6, nitric oxide (NO), and tumor necrosis factor (TNF- $\alpha$ ) induced by LPS in bovine mammary epithelial cells [80]. This mechanism is essential for regulating udder reactions to infection as it controls the chronic accumulation of neutrophils in the bovine mammary gland [81], whereas JAK also serves as a signaling agent for hormones and interleukin receptors [82] and JAK2 is considered one of the top-rated genes of bovine mastitis tolerance [83]. 


\subsection{Association of JAK2 Activity with Bovine Mastitis}

Any dysfunctions of the JAK-STAT pathway may expose cattle to mastitis because of abnormal activation of the proliferation and apoptosis of cells. From this point of view, it can be expected that mutations in genes involved in the JAK-STAT pathway might be a target in bovine mastitis research. The inflammatory- and immunity-associated diseases are polygenic traits [71], and polymorphisms in immunity-linked genes can regulate the immune responses of the host to pathogens [84]. Two major approaches are dominantly targeted by animal scientists to control mastitis. The first approach is to look for major genes associated with mastitis resistance, while the second one is to target the polymorphisms within genes and their links with mastitis resistance traits.

Many types of mutations in the JAK-STAT pathway have been identified; most of them are related to $J A K 2$.

As demonstrated in Table 1, the polymorphism 39630048C/T in JAK2 is associated with interleukin-17 (IL-17) [85], IL-6, and interferon-gamma (IFN- $\gamma$ ) expression [51]. Furthermore, the SNPs (39652267A/G, 39631175T/C) in the JAK2 gene have been documented for their significant links with milk somatic cell counts (SCCs), IL-6, and IFN- $\gamma$ [51,85]. Mutation 39631044G/A in the JAK2 gene was noticed to be significantly associated with milk somatic cell scores (SCSs) in Chinese Holsteins [85]. Moreover, the polymorphism 39645396C/T in the JAK2 gene was linked to milk SCCs, IL-6, and IFN- $\gamma$ [86], while SNP-39631044G/A in JAK2 was associated with milk SCSs [85]. SCCs and SCSs are widely targeted as early mastitis indicators [7]. Increased SCCs in early lactation can signify the presence of intramammary infection, and, in many countries, the indirect selection against mastitis using milk SCCs is practiced [87]. However, in the early phase of infectivity, the neutrophil and inflammatory cytokine levels increase quicker than milk SCCs [88]. That is why, nowadays, more interest is paid to the increase in cells and cytokine levels in milk and blood, respectively, rather than just the overall SCC, which may provide an early status of udder health [89]. A study showed that inflammatory cytokines (IL-6, IL-17, and IFN- $\gamma$, TNF- $\alpha$ ) could be used as subclinical mastitis indicators, in addition to SCSs and SCCs $[51,86,90]$. In addition, it is predicted that the 39645396C/T SNP changes lysine to asparagine [86]. The expression of IL-6 was higher in plasma cell mastitis (PCM), which indicated that the IL-6/STAT3 pathway could play a key role in the pathogenesis of PCM [22,91]. The IL-17 family consists of cytokines that participate in acute and chronic inflammation and provoke the host's defense against microbial organisms [92]. T-helper 17 cells are thought to be a significant source of IL-17A; furthermore, IL-17, producing innate immune cells, activate the fast release of IL-17A [93] in response to pathogens or tissue injury [94].

Table 1. Association of SNPs in JAK2 with bovine mastitis resistance phenotypic traits.

\begin{tabular}{lccccc}
\hline Gene & Mutation & Reference & Position & Phenotypic Traits & Authors \\
\hline JAK2 & C-T/EXON16 & rs210148032 & Chr8:39652267 & SCC & {$[51,85]$} \\
JAK2 & C-T/EXON20 & rs110298451 & Chr8:39645396 & IL-6, IFN- $\gamma$, SCC & {$[51,86]$} \\
JAK2 & C-T/3'flanking region & rs135128681 & Chr8:39630048 & IL-6, IFN- $\gamma$, SCC & {$[51,85]$} \\
JAK2 & T-C/3'flanking region & Novel & Chr8:39631175 & IL-6, SCC & {$[51,85]$} \\
JAK2 & G-A/3'flanking region & Novel & Chr8:39631044 & SCS & {$[85]$} \\
JAK2 & $5^{\prime}$ upstream & rs379754157 & Chr8:39750638 & SCC & {$[49]$} \\
\hline
\end{tabular}

IL-17 has been shown to be significantly upregulated in goat milk infected with E. coli or S. aureus [95]. IL-17A production was documented during S. uberis mastitis [96], and slightly increased expression was also noticed in the somatic cells of cows infected with S. aureus [97]. Furthermore, an in-vitro study illustrated that IL-17A reinforces the ability of mammary epithelial cells (MECs) to resist the consequences produced by $S$. aureus [98]. It has been reported that $I L-17 A$ and $I L-17 F$ play a critical role in regulating host-pathogen interactions during the development of mastitis [99]. The SNPs in $I L-17 F$ and $I L-17 A$ have been shown to be associated with milk SCCs [90]. Moreover, IL-17 also activates IL-6 with IFN- $\gamma$ and tumor necrosis factor-alpha (TNF- $\alpha$ ) [100]. Usman et al. revealed that 
IL-6 is the best indicator of mastitis and can be a target in mastitis control strategies [85]. Altogether, the above-published studies show that IL-17, IL-6, IL-4, IFN- $\gamma$, SCS, and SCC are the key indicators of mastitis. The interactions of polymorphisms in $J A K 2$ with bovine mastitis resistance phenotypic traits (IL-17, IL-6, IL-4, IFN- $\gamma$, SCS, and SCC) show that JAK2 might be considered a useful marker in bovine mastitis resistance strategies.

\subsection{Role of STATs in Bovine Mastitis}

A variety of cytokines and growth factors activate STATs, which are a family of latent transcription factors. During the process of inflammation, STAT5B regulates CD4+ T-cells differentiation [101]. STAT1 raised the expression of SOCS3 and SOCS1 in S. aureus-infected mammary epithelial cells [102]. Furthermore, it was reported that upon treatment with JAK inhibitors, the plasma cells in PCM decreased considerably due to the suppression of IL6/STAT/JAK signaling, resulting in the reversion of pathogenesis [91]. Accordingly, it was found that the inflammatory cytokines regulate the JAK-STAT pathway in the mammary gland; in response, the phosphorylation of STAT takes place. The phosphorylated STAT translocates into the nucleus and mediates the production of proinflammatory genes that facilitate mastitis's pathogenesis [78]. It is known that the inflammatory cells are recruited towards the site of infection, in which T-cells, particularly CD4+ cells, are predominantly observed in bovine mastitis [103]. Rivas et al. revealed that S. aureus-infected dairy cows showed a remarkable elevation in the level of CD4+ T-cells at the early stage of infection in the mammary gland [104]. Eder's team recently proved that the CD4+T-cell level was higher in dry cows compared to lactating cows. These findings show that a decrease in the level of CD4+ T-cells in lactating dairy might be one of the reasons for susceptibility to infection during this stage [105]. Usman et al. reported a significant association of variant T104010752C in the CD4 gene with milk SCCs [90]. In the previous study, it was noticed that polymorphisms in CD4 and STAT5B genes are significantly linked with mastitis-resistance phenotypic traits [83]. Furthermore, the polymorphism in CD4 at locus g.13598C $>$ T showed a significant association with SCS, which is the crucial indicator of mastitis.

The combination geneotype analysis of CD4 g.13598C > T and STAT5b g.31562 T $>$ C is associated with milk SCSs in Chinese Holsteins. Furthermore, it was reported that cows with combination genotypes of CCTT show the highest estimated breeding value (EBV) for SCSs [71]. Another study documented that the silencing of the CD4 gene through DNA methylation influences the progress of CD4+ T-cells in inflammatory conditions [106]. These findings demonstrate that CD4 protein and CD4+ T-cells play essential roles in host defense during the development of mastitis.

As demonstrated in Table 2, the polymorphism in STAT5A (43046497A/C) is associated with IL-6 and also changes the amino acid isoleucine to valine [85]. Similarly, mutation at point 43673888A $>\mathrm{G}$ in the STAT5B gene was significantly linked to mastitis-resistance phenotypic traits (IL-4 and SCC) [86]. Bochniarz et al. reported the elevated level of IL- 6 and decreased level of IL-4 in the milk and serum of cows infected with S. aureus [107]. In addition, the polymorphism STAT5A-AvaI was associated with milk SCCs and electrical conductivity (EC) in the milk of mastitic cows [108]. EC in milk is one of the essential indicators of bovine mastitis because of its association with $\mathrm{Na}$ and $\mathrm{Cl}$ levels, which increase during mastitis. Cai et al. also reported a STAT5A gene through genomewide association studies (GWAS) as a potential candidate marker for bovine mastitis resistance [109]. Based on the above-published findings, we concluded that STAT5A and STAT5B might be target mastitis-resistance markers in dairy cattle.

Table 2. Association of SNPs in STAT5A and STAT5B with bovine mastitis resistance phenotypic traits.

\begin{tabular}{cccccc}
\hline Gene & Mutation & Reference & Position & Phenotypic Traits & Authors \\
\hline STAT5A & A-C/Intron 9 & rs109358395 & Chr19:43046497 & IL-6 & [85] \\
STAT5B & A-G/Intron 4 & rs41915686 & Chr19:43673888 & IL-4, SCC & [86] \\
STAT5b & T-C/EXON 8 & & Chr19:31562 & SCS & [71] \\
\hline
\end{tabular}




\section{Inhibitors of the JAK-STAT Pathway: Role in Mastitis and Milk Production}

The protein inhibitors of activated STAT (PIAS) [110], protein tyrosine phosphatases (PTPs) [111], and cytokine signaling suppressors (SOCSs) [112] are three major classes used by cells to control the JAK-STAT pathway [113]. PIAS proteins are considered important transcriptional coregulators of JAK-STAT signaling because of their significant contribution to the control of gene expression [114]. PIAS proteins restrict the regulation of the JAK-STAT pathway in three ways: (1) by adding a small ubiquitin-like modifier (SUMO) group to STAT and blocking its phosphorylation, (2) by preventing the binding of STAT to DNA [115], and (3) by recruiting histone deacetylase to remove acetyl changes to histones by lowering gene expression [116]. Similarly, PIAS3, a member of the PIAS family, has been identified to inhibit STAT3 signaling after regulation by the cytokine IL-6 [117]. Moreover, PIAS1 could inhibit NF-KB and JAK-STAT activity regulated by cytokine TNF and the LPS endotoxin [110]. PIAS has a major role in cell proliferation [118], cell apoptosis, and the immune response [115]. Protein tyrosine phosphatases (PTPs) are a group of enzymes that remove the phosphate group from the JAK-STAT pathway and prevent the action of signaling [119]. The STATs are deactivated by PTPS in both the nucleus and cytoplasm. Src homology phosphatase 2 (SHP-2) is one of the members of PTPs that inactivate STAT5 in the cytoplasm. Similarly, SHP1 prevents the phosphorylation of the JAK-STAT pathway and blocks its further action $[120,121]$. The general role of JAK-STAT inhibitors has been summarized by recently published reviews in more detail [31,122]. Although the two groups of PTPs and PIAS have essential roles in the regulation of the JAK-STAT pathway, their tasks have not been evaluated in milk production or bovine mastitis to date. Therefore, we have only focused on cytokine signaling suppressors (SOCSs) in our current review.

Some SOCS proteins are triggered by cytokines and pathogenic mediators and, thus, function in a classical negative-feedback loop to impede the transduction of cytokine signals. Consequently, they represent an effective mechanism for the negative regulation of the cytokine-mediated JAK-STAT pathway [123]. The DNA binding of STAT protein regulates the mRNA expression of SOCSs [124]. SOCS3 can inhibit JAK tyrosine kinase activity directly via its kinase-inhibitory region (KIR), which has been proposed to serve as a pseudosubstrate and is essential for cytokine signal suppression [125]. Undeniably, both a KIR and a KIR-mimetic peptide, classified as the tyrosine kinase inhibitor peptide (TKIP), have been described to inhibit JAK2-regulated transcription factor STAT1 phosphorylation $[126,127]$. The SH2 domain of SOCS can also directly bind to the receptors and prevent the signal from passing to JAK-STAT signaling [128]. Moreover, Kimura et al. revealed that LPS could activate JAK2 and STAT5, which participate in the induction of IL-6, while SOCS1 inhibits this process selectively [129].

The suppression of IL- 6 and IFN- $\gamma$ usually occurs around parturition, which depresses immunity and exposes dairy cattle to mastitis [130]. Normal levels of IL- 6 and IFN- $\gamma$ are necessary for the maintenance of bovine immunity. Moreover, SOCS3 has been reported to be one of the key inhibitors of IL-6 and IFN-gamma. This evidence shows that SOCS3 might have a potential role in mastitis development in dairy cattle [131]. Moreover, Fang et al. found that SOCS3 was significantly upregulated after the mammary gland had been infected with S. aureus. The authors further supposed that SOCS3 could negatively regulate the JAK-STAT pathway, which might be one of the reasons for its critical role in mastitis development [132]. Huang et al. also reported that SOCS3 is a negative regulator of the JAK-STAT pathway. Furthermore, it was demonstrated that overexpression and inhibition of SOCS3 brought visible changes in milk protein, which might be due to the action of SOCS3 on the JAK-STAT pathway [133]. The Huang team further suggested that a low level of SOCS3 is essential for the regulation of milk synthesis. Similarly, a study reported that SOCS3 inhibits the induction of Prl and activation of STAT5 [134]. Zahoor et al. found that merTK reduces the inflammatory changes induced by $S$. aureus through STATs/SOCS3 signaling [102]. Furthermore, it has been revealed that impaired SOCS1/3 has a crucial role in the susceptibility of mammary epithelial cells to $S$. aureus infections. Additionally, a study reported a polymorphism in SOCS2, which was significantly associated with susceptibility to inflammation of the mammary gland [135]. SOCS3 also has an inhibitory role in STAT5 
regulation, which is one of the strong reasons for their influence on lactational performance in dairy cattle. Further study is highly recommended to find out the specific variants in SOCS3 that interact with STAT5 and JAK2 during mastitis development and milk production in dairy cattle.

\section{Conclusions}

Altogether, it can be concluded that a delicate equilibrium must be achieved for the effective activation of the JAK/STAT pathway, when the immune system is needed for action against infection, and proper restoration when the infection is diminished. Thus, the JAK-STAT pathway can be considered as a therapeutic option in mastitis control and enhancement of milk production strategies. Furthermore, it is suggested that the interactive mechanism of SOCS3, STATs, and JAK2, STAT5A, and $S T A T 5 B$ during milk production and mastitis development should be considered in future rodent-knockout research models. It is highly recommended that further polymorphisms in STAT1 and SOCS3 and their associations with milk production and mastitis resistance traits be found out. Finally, PTPs and PIAS are critical inhibitors of the JAK-STAT pathway, so research on the evaluation of their role in bovine mastitis would be an interesting development.

Author Contributions: Conceptualization, M.Z.K. and Z.C.; writing-original draft preparation, M.Z.K. and A.K.; writing-review and editing, M.Z.K., Y.M., J.G., J.X., J.M., and Z.C. All authors have read and agreed to the published version of the manuscript.

Funding: The review is supported by the National Key Research and Development Program of China (2018YFD0501600). The funder has no role in study design, data collection, analysis, decision to publish, and preparation of the manuscript.

Acknowledgments: We acknowledge the financial support of the National Key Research and Development Program of China (2018YFD0501600). We also acknowledge China Agricultural University, Beijing, China, for providing us an environment of learning. Without this platform, the completion of this work would not have been an easy task.

Conflicts of Interest: The authors declare that they have no competing interests.

\section{References}

1. Szyda, J.; Mielczarek, M.; Fraęszczak, M.; Minozzi, G.; Williams, J.L.; Wojdak-Maksymiec, K. The genetic background of clinical mastitis in Holstein-Friesian cattle. Animal 2019, 13, 2156-2163. [CrossRef] [PubMed]

2. Mansor, R.; Mullen, W.; Albalat, A.; Zerefos, P.; Mischak, H.; Barrett, D.C.; Biggs, A.; Eckersall, P.D. A peptidomic approach to biomarker discovery for bovine mastitis. J. Proteom. 2013, 85, 89-98. [CrossRef] [PubMed]

3. Wang, J.J.; Wei, Z.K.; Zhang, X.; Wang, Y.N.; Fu, Y.H.; Yang, Z.T. Butyrate protects against disruption of the blood-milk barrier and moderates inflammatory responses in a model of mastitis induced by lipopolysaccharide. Br. J. Pharmacol. 2017, 174, 3811-3822. [CrossRef] [PubMed]

4. Yang, C.; Liu, P.; Wang, S.; Zhao, G.; Zhang, T.; Guo, S.; Jiang, K.F.; Wu, H.C.; Deng, G. Shikonin exerts anti-inflammatory effects in LPS-induced mastitis by inhibiting NF- $\mathrm{kB}$ signaling pathway. Biochem. Biophys. Res. Commun. 2018, 505, 1-6. [CrossRef] [PubMed]

5. Pumipuntu, N.; Kulpeanprasit, S.; Santajit, S.; Tunyong, W.; Kong-ngoen, T.; Hinthong, W.; Indrawattana, N. Screening method for Staphylococcus aureus identification in subclinical bovine mastitis from dairy farms. Vet. World 2017, 10, 721-726. [CrossRef] [PubMed]

6. Jensen, K.; Günther, J.; Talbot, R.; Petzl, W.; Zerbe, H.; Schuberth, H.J.; Seyfert, H.M.; Glass, E.J. Escherichia coliand Staphylococcus aureus-induced mastitis differentially modulate transcriptional responses in neighbouring uninfected bovine mammary gland quarters. BMC Genom. 2013, 14, 36. [CrossRef]

7. Wang, L.; Yang, F.; Wei, X.J.; Luo, Y.J.; Guo, W.Z.; Zhou, X.Z.; Guo, Z.T. Prevalence and risk factors of subclinical mastitis in lactating cows in Northwest China. Isr. J. Vet. Med. 2019, 74, 17-22.

8. Seegers, H.; Fourichon, C.; Beaudeau, F. Production effects related to mastitis and mastitis economics in dairy cattle herds. Vet. Res. 2003, 34, 475-491. [CrossRef] [PubMed]

9. Hamadani, H.; Khan, A.; Banday, M.; Ashraf, I.; Handoo, N.; Shah, A.; Hamadani, A. Bovine MastitisA Disease of Serious Concern for Dairy Farmers. Int. J. Livest. Res. 2013, 3, 42. [CrossRef] 
10. Viguier, C.; Arora, S.; Gilmartin, N.; Welbeck, K.; O'Kennedy, R. Mastitis detection: Current trends and future perspectives. Trends Biotechnol. 2009, 27, 486-493. Thompson-Crispi, K.; Atalla, H.; Miglior, F.; Mallard, B.A. Bovine mastitis: Frontiers in immunogenetics. Front. Immunol. 2014, 5, 1-10.

11. Thompson-Crispi, K.; Atalla, H.; Miglior, F.; Mallard, B.A. Bovine mastitis: Frontiers in immunogenetics. Front. Immunol. 2014, 5, 1-10. [CrossRef] [PubMed]

12. González, R.N.; Wilson, D.J. Mycoplasmal mastitis in dairy herds. Vet. Clin. North Am. Food Anim. Pract. 2003, 19, 199-221. [CrossRef]

13. Wellnitz, O.; Bruckmaier, R.M. The innate immune response of the bovine mammary gland to bacterial infection. Vet. J. 2012, 192, 148-152. [CrossRef] [PubMed]

14. Brenaut, P.; Lefèvre, L.; Rau, A.; Laloë, D.; Pisoni, G.; Moroni, P.; Bevilacqua, C.; Martin, P. Contribution of mammary epithelial cells to the immune response during early stages of a bacterial infection to Staphylococcus aureus. Vet. Res. 2014, 45. [CrossRef]

15. Segal, S.; Hill, A.V.S. Genetic susceptibility to infectious disease. Trends Microbiol. 2003, 11, 445-448. [CrossRef]

16. Albiger, B.; Dahlberg, S.; Henriques-Normark, B.; Normark, S. Role of the innate immune system in host defence against bacterial infections: Focus on the Toll-like receptors. J. Intern. Med. 2007, 261, 511-528. [CrossRef]

17. Bhattarai, D.; Worku, T.; Dad, R.; Rehman, Z.U.; Gong, X.; Zhang, S. Mechanism of pattern recognition receptors (PRRs) and host pathogen interplay in bovine mastitis. Microb. Pathog. 2018, 120, 64-70. [CrossRef]

18. Brooks, A.J.; Dai, W.; O’Mara, M.L.; Abankwa, D.; Chhabra, Y.; Pelekanos, R.A.; Gardon, O.; Tunny, K.A.; Blucher, K.M.; Morton, C.J.; et al. Mechanism of activation of protein kinase JAK2 by the growth hormone receptor. Science 2014, 344, 1249783. [CrossRef]

19. Liongue, C.; Ward, A.C. Evolution of the JAK-STAT pathway. JAKSTAT 2013, 2, e22756. [CrossRef]

20. Liu, X.; Robinson, G.W.; Gouilleux, F.; Groner, B.; Hennighausen, L. Cloning and expression of Stat5 and an additional homologue (Stat5b) involved in prolactin signal transduction in mouse mammary tissue. Proc. Natl. Acad. Sci. USA 1995, 92, 8831-8835. [CrossRef]

21. Hennighausen, L.; Robinson, W.G. Signaling Pathways in Mammary Gland Development. Dev. Cell 2001, 1, 467-475. [CrossRef]

22. Furth, P.A.; Nakles, R.E.; Millman, S.; Diaz-Cruz, E.S.; Cabrera, M.C. Signal transducer and activator of transcription 5 as a key signaling pathway in normal mammary gland developmental biology and breast cancer. Breast Cancer Res. 2011, 13. [CrossRef] [PubMed]

23. Ersahin, T.; Tuncbag, N.; Cetin-Atalay, R. The PI3K/AKT/mTOR interactive pathway. Mol. Biosyst. 2015, 11, 1946-1954. [CrossRef]

24. Sobolewska, A.; Gajewska, M.; Zarzyńska, J.; Gajkowska, B.; Motyl, T. IGF-I, EGF, and sex steroids regulate autophagy in bovine mammary epithelial cells via the mTOR pathway. Eur. J. Cell Biol. 2009, 88, 117-130. [CrossRef]

25. Schmidt, J.W.; Wehde, B.L.; Sakamoto, K.; Triplett, A.A.; Anderson, S.M.; Tsichlis, P.N.; Leone, G.; Wagner, K.-U. Stat5 Regulates the Phosphatidylinositol 3-Kinase/Akt1 Pathway during Mammary Gland Development and Tumorigenesis. Mol. Cell. Biol. 2014, 34, 1363-1377. [CrossRef]

26. Huang, D.W.; Sherman, B.T.; Lempicki, R.A. Systematic and integrative analysis of large gene lists using DAVID bioinformatics resources. Nat. Protoc. 2009, 4, 44-57. [CrossRef]

27. Vafaizadeh, V.; Klemmt, P.A.B.; Groner, B. Stat5 assumes distinct functions in mammary gland development and mammary tumor formation. Front. Biosci. 2012, 17, 1232-1250. [CrossRef] [PubMed]

28. Rawlings, J.S.; Rosler, K.M.; Harrison, D.A. The JAK/STAT signaling pathway. J. Cell Sci. 2004, 117, 1281-1283. [CrossRef]

29. Zhou, G.Y.; Yi, Y.X.; Jin, L.X.; Lin, W.; Fang, P.P.; Lin, X.Z.; Zheng, Y.; Pan, C.W. The protective effect of juglanin on fructose-induced hepatitis by inhibiting inflammation and apoptosis through TLR4 and JAK2/STAT3 signaling pathways in fructose-fed rats. Biomed. Pharmacother. 2016, 81, 318-328. [CrossRef] [PubMed]

30. Zhang, C.; Liu, J.; Yuan, C.; Ji, Q.; Chen, D.; Zhao, H.; Jiang, W.; Ma, K.; Liu, L. JAK2/STAT3 is associated with the inflammatory process in periapical granuloma. Int. J. Clin. Exp. Pathol. 2019, 12, 190-197.

31. Xin, P.; Xu, X.; Deng, C.; Liu, S.; Wang, Y.; Zhou, X.; Ma, H.; Wei, D.; Sun, S. The role of JAK/STAT signaling pathway and its inhibitors in diseases. Int. Immunopharmacol. 2020, 80, 106210. [CrossRef] 
32. Villarino, A.V.; Kanno, Y.; Shea, J.J.O. Mechanism and consequences of JAK/STAT signaling in the immune system. Nat. Immunol. 2017, 18, 374-384. [CrossRef]

33. Kiu, H.; Nicholson, S.E. Biology and significance of the JAK/STAT signalling pathways. Growth Factors 2012, 30, 88-106. [CrossRef]

34. Bionaz, M.; Loor, J.J. Gene networks driving bovine mammary protein synthesis during the lactation cycle. Bioinform. Biol. Insights 2011, 5, 83-98. [CrossRef]

35. Brenaut, P.; Bangera, R.; Bevilacqua, C.; Rebours, E.; Cebo, C.; Martin, P. Validation of RNA isolated from milk fat globules to profile mammary epithelial cell expression during lactation and transcriptional response to a bacterial infection. J. Dairy Sci. 2012, 95, 6130-6144. [CrossRef]

36. Yamaji, D.; Kang, K.; Robinson, G.W.; Hennighausen, L. Sequential activation of genetic programs in mouse mammary epithelium during pregnancy depends on STAT5A/Bconcentration. Nucleic Acids Res. 2013, 41, 1622-1636. [CrossRef] [PubMed]

37. Hennighausen, L.; Robinson, G.W.; Wagner, K.U.; Liu, X. Developing a mammary gland is a stat affair. J. Mammary Gland Biol. Neoplasia 1997, 2, 365-372. [CrossRef]

38. Arun, S.J.; Thomson, P.C.; Sheehy, P.A.; Khatkar, M.S.; Raadsma, H.W.; Williamson, P. Targeted Analysis Reveals an Important Role of JAK-STAT-SOCS Genes for Milk Production Traits in Australian Dairy Cattle. Front. Genet. 2015, 6, 342. [CrossRef]

39. Briscoe, J.; Guschin, D.; Müller, M. Signal Transduction: Just another signalling pathway. Curr. Biol. 1994, 4, 1033-1035. [CrossRef]

40. Groner, B.; Gouilleux, F. Prolactin-mediated gene activation in mammary epithelial cells. Curr. Opin. Genet. Dev. 1995, 5, 587-594. [CrossRef]

41. Sigl, T.; Meyer, H.H.D.; Wiedemann, S. Gene expression analysis of protein synthesis pathways in bovine mammary epithelial cells purified from milk during lactation and short-term restricted feeding. J. Anim. Physiol. Anim. Nutr. 2014, 98, 84-95. [CrossRef]

42. Tian, Q.; Wang, H.R.; Wang, M.Z.; Wang, C.; Liu, S.M. Lactogenic hormones regulate mammary protein synthesis in bovine mammary epithelial cells via the mTOR and JAK-STAT signal pathways. Anim. Prod. Sci. 2016, 56, 1803-1809. [CrossRef]

43. Bole-Feysot, C. Prolactin (PRL) and Its Receptor: Actions, Signal Transduction Pathways and Phenotypes Observed in PRL Receptor Knockout Mice. Endocr. Rev. 1998, 19, 225-268. [CrossRef]

44. Auchtung, T.L.; Rius, A.G.; Kendall, P.E.; McFadden, T.B.; Dahl, G.E. Effects of photoperiod during the dry period on prolactin, prolactin receptor, and milk production of dairy cows. J. Dairy Sci. 2005, 88, 121-127. [CrossRef]

45. Campo Verde Arboccó, F.; Persia, F.A.; Hapon, M.B.; Jahn, G.A. Hypothyroidism decreases JAK/STAT signaling pathway in lactating rat mammary gland. Mol. Cell. Endocrinol. 2017, 450, 14-23. [CrossRef]

46. Shillingford, J.M.; Miyoshi, K.; Robinson, G.W.; Grimm, S.L.; Rosen, J.M.; Neubauer, H.; Pfeffer, K.; Hennighausen, L. Jak2 is an essential tyrosine kinase involved in pregnancy-mediated development of mammary secretory epithelium. Mol. Endocrinol. 2002, 16, 563-570. [CrossRef]

47. Etherton, T.D.; Bauman, D.E. Biology of somatotropin in growth and lactation of domestic animals. Physiol. Rev. 1998, 78, 745-761. [CrossRef]

48. Liu, X.F.; Li, M.; Li, Q.Z.; Lu, L.M.; Tong, H.L.; Gao, X.J. Stat5a increases lactation of dairy cow mammary gland epithelial cells cultured in vitro. Vitr. Cell. Dev. Biol. Anim. 2012, 48, 554-561. [CrossRef]

49. Ali, N.; Niaz, S.; Khan, N.U.; Gohar, A.; Khattak, I.; Dong, Y.; Khattak, T.; Ahmad, I.; Wang, Y.; Usman, T. Polymorphisms in JAK2 Gene are Associated with Production Traits and Mastitis Resistance in Dairy Cattle. Ann. Anim. Sci. 2019, 20, 409-423. [CrossRef]

50. Szewczuk, M. Association of a genetic marker at the bovine Janus kinase 2 locus (JAK2/RsaI) with milk production traits of four cattle breeds. J. Dairy Res. 2015, 82, 287-292. [CrossRef]

51. Khan, M.Z.; Wang, D.; Liu, L.; Usman, T.; Wen, H.; Zhang, R.; Liu, S.; Shi, L.; Mi, S.; Xiao, W.; et al. Significant genetic effects of JAK2 and DGAT1 mutations on milk fat content and mastitis resistance in Holsteins. J. Dairy Res. 2019, 86, 388-393. [CrossRef] [PubMed]

52. Meredith, B.K.; Kearney, F.J.; Finlay, E.K.; Bradley, D.G.; Fahey, A.G.; Berry, D.P.; Lynn, D.J. Genome-wide associations for milk production and somatic cell score in Holstein-Friesian cattle in Ireland. BMC Genet. 2012, 13, 21. [CrossRef] 
53. Verdier, F.; Rabionet, R.; Gouilleux, F.; Beisenherz-Huss, C.; Varlet, P.; Muller, O.; Mayeux, P.; Lacombe, C.; Gisselbrecht, S.; Chretien, S. A sequence of the CIS gene promoter interacts preferentially with two associated STAT5A dimers: A distinct biochemical difference between STAT5A and STAT5B. Mol. Cell. Biol. 1998, 20, 389-401. [CrossRef] [PubMed]

54. Bao, B.; Zhang, C.; Fang, X.; Zhang, R.; Gu, C.; Lei, C.; Chen, H. Association between polymorphism in STAT5A gene and milk production traits in chinese holstein cattle. Anim. Sci. Pap. Rep. 2010, 28, 5-11.

55. Liu, X.; Robinson, G.W.; Wagner, K.U.; Garrett, L.; Wynshaw-Boris, A.; Hennighausen, L. Stat5a is mandatory for adult mammary gland development and lactogenesis. Genes Dev. 1997, 11, 179-186. [CrossRef]

56. Bionaz, M.; Periasamy, K.; Rodriguez-Zas, S.L.; Everts, R.E.; Lewin, H.A.; Hurley, W.L.; Loor, J.J. Old and new stories: Revelations from functional analysis of the bovine mammary transcriptome during the lactation cycle. PLoS ONE 2012, 7. [CrossRef]

57. Lacasse, P.; Ollier, S.; Lollivier, V.; Boutinaud, M. New insights into the importance of prolactin in dairy ruminants. J. Dairy Sci. 2016, 99, 864-874. [CrossRef]

58. Watson, C.J.; Neoh, K. The Stat family of transcription factors have diverse roles in mammary gland development. Semin. Cell. Dev. Biol. 2008, 19, 401-406. [CrossRef]

59. Teglund, S.; McKay, C.; Schuetz, E.; Van Deursen, J.M.; Stravopodis, D.; Wang, D.; Brown, M.; Bodner, S.; Grosveld, G.; Ihle, J.N. Stat5a and Stat5b proteins have essential and nonessential, or redundant, roles in cytokine responses. Cell 1998, 93, 841-850. [CrossRef]

60. Dong, B.; Zhao, F.Q. Involvement of the ubiquitous Oct-1 transcription factor in hormonal induction of $\beta$-casein gene expression. Biochem. J. 2007, 401, 57-64. [CrossRef]

61. Ji, M.-R.; Lee, S.I.; Jang, Y.J.; Jeon, M.-H.; Kim, J.S.; Kim, K.W.; Park, J.K.; Yoo, J.G.; Jeon, I.S.; Kwon, D.J.; et al. STAT5 plays a critical role in regulating the $5^{\prime}$-flanking region of the porcine whey acidic protein gene in transgenic mice. Mol. Reprod. Dev. 2015, 82, 957-966. [CrossRef]

62. Watson, C.J. Stat transcription factors in mammary gland development and tumorigenesis. J. Mammary Gland Biol. Neoplasia. 2001, 6, 115-127. [CrossRef]

63. Boutinaud, M.; Jammes, H. Growth hormone increases Stat 5 and Stat 1 expression in lactating goat mammary gland: A specific effect compared to milking frequency. Domest. Anim. Endocrinol. 2004, 27, 363-378. [CrossRef]

64. Sadeghi, M.; Shahrbabak, M.M.; Mianji, G.R.; Javaremi, A.N. Polymorphism at locus of STAT5A and its association with breeding values of milk production traits in Iranian Holstein bulls. Livest. Sci. 2009, 123, 97-100. [CrossRef]

65. Selvaggi, M.; Albarella, S.; Dario, C.; Peretti, V.; Ciotola, F. Association of STAT5A Gene Variants with Milk Production Traits in Agerolese Cattle. Biochem. Genet. 2017, 55, 158-167. [CrossRef] [PubMed]

66. Selvaggi, M.; Dario, C.; Normanno, G.; Celano, G.V.; Dario, M. Genetic polymorphism of STAT5A protein: Relationships with production traits and milk composition in Italian Brown cattle. J. Dairy Res. 2009, 76, 441-445. [CrossRef]

67. Dario, C.; Selvaggi, M. Study on the STAT5A/AvaI polymorphism in Jersey cows and association with milk production traits. Mol. Biol. Rep. 2011, 38, 5387-5392. [CrossRef] [PubMed]

68. He, X.; Chu, M.X.; Qiao, L.; He, J.N.; Wang, P.Q.; Feng, T.; Di, R.; Cao, G.L.; Fang, L.; An, Y.F. Polymorphisms of STAT5A gene and their association with milk production traits in Holstein cows. Mol. Biol. Rep. 2012, 39, 2901-2907. [CrossRef]

69. Schennink, A.; Bovenhuis, H.; Léon-Kloosterziel, K.M.; Van Arendonk, J.A.M.; Visker, M.H.P.W. Effect of polymorphisms in the FASN, OLR1, PPARGC1A, PRL and STAT5A genes on bovine milk-fat composition. Anim. Genet. 2009, 40, 909-916. [CrossRef]

70. Khatib, H.; Monson, R.L.; Schutzkus, V.; Kohl, D.M.; Rosa, G.J.M.; Rutledge, J.J. Mutations in the STAT5A gene are associated with embryonic survival and milk composition in cattle. J. Dairy Sci. 2008, 91, 784-793. [CrossRef]

71. He, Y.; Chu, Q.; Ma, P.; Wang, Y.; Zhang, Q.; Sun, D.; Zhang, Y.; Yu, Y.; Zhang, Y. Association of bovine CD4 and STAT5b single nucleotide polymorphisms with somatic cell scores and milk production traits in Chinese Holsteins. J. Dairy Res. 2011, 78, 242-249. [CrossRef]

72. Li, S.; Rosen, J.M. Nuclear factor I and mammary gland factor (STAT5) play a critical role in regulating rat whey acidic protein gene expression in transgenic mice. Mol. Cell. Biol. 1995, 15, 2063-2070. [CrossRef] 
73. Cobanoglu, O.; Zaitoun, I.; Chang, Y.M.; Shook, G.E.; Khatib, H. Effects of the Signal Transducer and Activator of Transcription 1 (STAT1) Gene on Milk Production Traits in Holstein Dairy Cattle. J. Dairy Sci. 2006, 89, 4433-4437. [CrossRef]

74. Cobanoglu, O.; Zaitoun, I.; Chang, Y.M.; Shook, G.E.; Khatib, H. The Detection of STAT1 Gene Influencing Milk Related Traits in Turkish Holstein and Jersey Cows. J. Agric. Sci. Technol. A 2016, 6, 261-269. [CrossRef]

75. Deng, T.X.; Pang, C.Y.; Lu, X.R.; Zhu, P.; Duan, A.Q.; Liang, X.W. Associations between polymorphisms of the STAT1 gene and milk production traits in water buffaloes1. J. Anim. Sci. 2016, 94, 927-935. [CrossRef]

76. Buitenhuis, B.; Røntved, C.M.; Edwards, S.M.; Ingvartsen, K.L.; Sørensen, P. In depth analysis of genes and pathways of the mammary gland involved in the pathogenesis of bovine Escherichia coli-mastitis. BMC Genom. 2011, 12. [CrossRef]

77. Tiezzi, F.; Parker-Gaddis, K.L.; Cole, J.B.; Clay, J.S.; Maltecca, C. A Genome-Wide Association Study for Clinical Mastitis in First Parity US Holstein Cows Using Single-Step Approach and Genomic Matrix Re-Weighting Procedure. PLoS ONE 2015, 10, e0114919. [CrossRef] [PubMed]

78. Han, H.S.; Shin, J.S.; Lee, S.B.; Park, J.C.; Lee, K.T. Cirsimarin, a flavone glucoside from the aerial part of Cirsium japonicum var. ussuriense (Regel) Kitam. ex Ohwi, suppresses the JAK/STAT and IRF-3 signaling pathway in LPS-stimulated RAW 264.7 macrophages. Chem. Biol. Interact. 2018, 293, 38-47. [CrossRef]

79. Li, J.; Yin, P.; Gong, P.; Lv, A.; Zhang, Z.; Liu, F. 8-Methoxypsoralen protects bovine mammary epithelial cells against lipopolysaccharide-induced inflammatory injury via suppressing JAK/STAT and NF- $\mathrm{KB}$ pathway. Microbiol. Immunol. 2019, 63, 427-437. [CrossRef]

80. Lee, S.B.; Lee, W.S.; Shin, J.S.; Jang, D.S.; Lee, K.T. Xanthotoxin suppresses LPS-induced expression of iNOS, COX-2, TNF- $\alpha$, and IL-6 via AP-1, NF- $\mathrm{BB}$, and JAK-STAT inactivation in RAW 264.7 macrophages. Int. Immunopharmacol. 2017, 49, 21-29. [CrossRef]

81. Boutet, P.; Boulanger, D.; Gillet, L.; Vanderplasschen, A.; Closset, R.; Bureau, F.; Lekeux, P. Delayed neutrophil apoptosis in bovine subclinical mastitis. J. Dairy Sci. 2004, 87, 4104-4114. [CrossRef]

82. Moyes, K.M.; Drackley, J.K.; Morin, D.E.; Bionaz, M.; Rodriguez-Zas, S.L.; Everts, R.E.; Lewin, H.A.; Loor, J.J. Gene network and pathway analysis of bovine mammary tissue challenged with Streptococcus uberis reveals induction of cell proliferation and inhibition of PPAR signaling as potential mechanism for the negative relationships between immune response and lipi. BMC Genom. 2009, 10. [CrossRef]

83. Jiang, L.; Sørensen, P.; Thomsen, B.; Edwards, S.M.; Skarman, A.; Røntved, C.M.; Lund, M.S.; Workman, C.T. Gene prioritization for livestock diseases by data integration. Physiol. Gen. 2011, 44, 283-330. [CrossRef]

84. Yue, Y.; QiuLing, L.; ZhiHua, J.; JinMing, H.; Lei, Z.; RongLing, L.; JianBin, L.; FangXiong, S.; JiFeng, Z.; ChangFa, W. Three novel single-nucleotide polymorphisms of complement component 4 gene $(\mathrm{C} 4 \mathrm{~A})$ in Chinese Holstein cattle and their associations with milk performance traits and $\mathrm{CH} 50$. Vet. Immunol. Immunopathol. 2012, 145, 223-232.

85. Usman, T.; Yu, Y.; Liu, C.; Wang, X.; Zhang, Q.; Wang, Y. Genetic effects of single nucleotide polymorphisms in JAK2 and STAT5A genes on susceptibility of Chinese Holsteins to mastitis. Mol. Biol. Rep. 2014, 41, 8293-8301. [CrossRef]

86. Usman, T.; Wang, Y.; Liu, C.; Wang, X.; Zhang, Y.; Yu, Y. Association study of single nucleotide polymorphisms in JAK2 and STAT5B genes and their differential mRNA expression with mastitis susceptibility in Chinese Holstein cattle. Anim. Genet. 2015, 46, 371-380. [CrossRef] [PubMed]

87. Weigel, K.A.; Shook, G.E. Genetic Selection for Mastitis Resistance. Vet. Clin. N. Am. Food Anim. Pract. 2018, 34, 457-472. [CrossRef]

88. Pilla, R.; Schwarz, D.; König, S.; Piccinini, R. Microscopic differential cell counting to identify inflammatory reactions in dairy cow quarter milk samples. J. Dairy Sci. 2012, 95, 4410-4420. [CrossRef]

89. Schwarz, D.; Rivas, A.L.; König, S.; Diesterbeck, U.S.; Schlez, K.; Zschöck, M.; Wolter, W.; Czerny, C.P. CD2/CD21 index: A new marker to evaluate udder health in dairy cows. J. Dairy Sci. 2013, 96, 5106-5119. [CrossRef]

90. Usman, T.; Wang, Y.; Song, M.; Wang, X.; Dong, Y.; Liu, C.; Wang, S.; Zhang, Y.; Xiao, W.; Yu, Y. Novel polymorphisms in bovine CD4 and LAG-3 genes associated with somatic cell counts of clinical mastitis cows. Genet. Mol. Res. 2017, 16. [CrossRef]

91. Liu, Y.; Zhang, J.; Zhou, Y.H.; Jiang, Y.N.; Zhang, W.; Tang, X.J.; Ren, Y.; Han, S.P.; Liu, P.J.; Xu, J.; et al. IL-6/STAT3 signaling pathway is activated in plasma cell mastitis. Int. J. Clin. Exp. Pathol. 2015, 8, 12541-12548. 
92. Milner, J.D. IL-17 producing cells in host defense and atopy. Curr. Opin. Immunol. 2011, 23, 784-788. [CrossRef]

93. Cua, D.J.; Tato, C.M. Innate IL-17-producing cells: The sentinels of the immune system. Nat. Rev. Immunol. 2010, 10, 479-489. [CrossRef]

94. Shibata, K.; Yamada, H.; Hara, H.; Kishihara, K.; Yoshikai, Y. Resident V $\delta 1+\gamma \delta \mathrm{T}$ Cells Control Early Infiltration of Neutrophils after Escherichia coli Infection via IL-17 Production. J. Immunol. 2007, 178, 4466-4472. [CrossRef] [PubMed]

95. Jing, X.Q.; Zhao, Y.Q.; Shang, C.C.; Yao, Y.L.; Tian, T.T.; Li, J.; Chen, D.K. Dynamics of cytokines associated with IL-17 producing cells in serum and milk in mastitis of experimental challenging with Staphylococcus aureus and Escherichia coli in dairy goats. J. Anim. Vet. Adv. 2012, 11, 475-479.

96. Tassi, R.; McNeilly, T.N.; Fitzpatrick, J.L.; Fontaine, M.C.; Reddick, D.; Ramage, C.; Lutton, M.; Schukken, Y.H.; Zadoks, R.N. Strain-specific pathogenicity of putative host-adapted and nonadapted strains of Streptococcus uberis in dairy cattle. J. Dairy Sci. 2013, 96, 5129-5145. [CrossRef]

97. Tao, W.; Mallard, B. Differentially expressed genes associated with Staphylococcus aureus mastitis of Canadian Holstein cows. Vet. Immunol. Immunopathol. 2007, 120, 201-211. [CrossRef]

98. Bougarn, S.; Cunha, P.; Gilbert, F.B.; Harmache, A.; Foucras, G.; Rainard, P. Staphylococcal-associated molecular patterns enhance expression of immune defense genes induced by IL-17 in mammary epithelial cells. Cytokine 2011, 56, 749-759. [CrossRef]

99. Roussel, P.; Cunha, P.; Porcherie, A.; Petzl, W.; Gilbert, F.B.; Riollet, C.; Zerbe, H.; Rainard, P.; Germon, P. Investigating the contribution of IL-17A and IL-17F to the host response during Escherichia coli mastitis. Vet. Res. 2015, 46. [CrossRef]

100. Ruddy, M.J.; Wong, G.C.; Liu, X.K.; Yamamoto, H.; Kasayama, S.; Kirkwood, K.L.; Gaffen, S.L. Functional Cooperation between Interleukin-17 and Tumor Necrosis Factor- $\alpha$ Is Mediated by CCAAT/Enhancer-binding Protein Family Members. J. Biol. Chem. 2004, 279, 2559-2567. [CrossRef]

101. Wilson, C.B.; Rowell, E.; Sekimata, M. Epigenetic control of T-helper-cell differentiation. Nat. Rev. Immunol. 2009, 9, 91-105. [CrossRef]

102. Zahoor, A.; Yang, Y.; Yang, C.; Khan, S.B.; Reix, C.; Anwar, F.; Deng, G. MerTK negatively regulates Staphylococcus aureus induced inflammatory response via Toll-like receptor signaling in the mammary gland. Mol. Immunol. 2020, 122, 1-12. [CrossRef]

103. Mehrzad, J.; Zhao, X. T lymphocyte proliferative capacity and CD4+/CD8+ ratio in primiparous and pluriparous lactating cows. J. Dairy Res. 2008, 75, 457-465. [CrossRef] [PubMed]

104. Rivas, A.L.; Schwager, S.J.; González, R.N.; Quimby, F.W.; Anderson, K.L. Multifactorial relationships between intramammary invasion by Staphylococcus aureus and bovine leukocyte markers. Can. J. Vet. Res. 2007, 71, 135-144.

105. Eder, J.M.; Gorden, P.J.; Lippolis, J.D.; Reinhardt, T.A.; Sacco, R.E. Lactation stage impacts the glycolytic function of bovine CD4+ T cells during ex vivo activation. Sci. Rep. 2020, 10. [CrossRef]

106. Wei, G.; Wei, L.; Zhu, J.; Zang, C.; Hu-Li, J.; Yao, Z.; Cui, K.; Kanno, Y.; Roh, T.Y.; Watford, W.T.; et al. Global Mapping of H3K4me3 and H3K27me3 Reveals Specificity and Plasticity in Lineage Fate Determination of Differentiating CD4+ T Cells. Immunity 2009, 30, 155-167. [CrossRef]

107. Bochniarz, M.; Zdzisińska, B.; Wawron, W.; Szczubiał, M.; Dąbrowski, R. Milk and serum IL-4, IL-6, IL-10, and amyloid A concentrations in cows with subclinical mastitis caused by coagulase-negative staphylococci. J. Dairy Sci. 2017, 100, 9674-9680. [CrossRef]

108. Kiyici, M.J.; Bilal, A.; Mahmut, K.; Korhan, A.; Esma, G.A.; Mehmet, U.C. Association of GH, STAT5A, MYF5 gene polymorphisms with milk somatic cell count, EC and $\mathrm{pH}$ levels of Holstein dairy cattle. Ani. Biotechnol. 2020. [CrossRef]

109. Cai, Z.; Guldbrandtsen, B.; Lund, M.S.; Sahana, G. Prioritizing candidate genes for fertility in dairy cows using gene-based analysis, functional annotation and differential gene expression. BMC Genom. 2019, 20, 255. [CrossRef]

110. Shuai, K. Regulation of cytokine signaling pathways by PIAS proteins. Cell Res. 2006, 16, 196-202. [CrossRef]

111. Henenstreit, D.; Horeks-Hoeck, J.; Duschl, A. JAK/STAT-dependent gene regulation by cytokines. Drug News Perspect. 2005, 18, 243. [CrossRef]

112. Krebs, D.L.; Hilton, D.J. SOCS proteins: Negative regulators of cytokine signaling. Stem Cells 2001, 19, 378-387. [CrossRef] [PubMed] 
113. Niu, G.J.; Xu, J.D.; Yuan, W.J.; Sun, J.J.; Yang, M.C.; He, Z.H.; Zhao, X.F.; Wang, J.X. Protein Inhibitor of Activated STAT (PIAS) Negatively Regulates the JAK/STAT Pathway by Inhibiting STAT Phosphorylation and Translocation. Front. Immunol. 2018, 9, 2392. [CrossRef]

114. Sharrocks, A.D. PIAS proteins and transcriptional regulation-More than just SUMO E3 ligases? Genes Dev. 2006, 20, 754-758. [CrossRef]

115. Shuai, K.; Liu, B.; Zhang, D.; Cui, Y.; Zhou, J.; Sheng, C. Regulation of gene-activation pathways by PIAS proteins in the immune system. Nat. Rev. Immunol. 2005, 5, 593-605. [CrossRef]

116. Ungureanu, D.; Vanhatupa, S.; Grönholm, J.; Palvimo, J.; Silvennoinen, O. SUMO-1 conjugation selectively modulates STAT1-mediated gene responses. Blood 2005, 106, 224-226. [CrossRef]

117. Chung, C.D.; Liao, J.; Liu, B.; Rao, X.; Jay, P.; Berta, P.; Shuai, K. Specific inhibition of Stat3 signal transduction by PIAS3. Science 1997, 278, 1803-1805. [CrossRef]

118. Tolkunova, E.; Malashicheva, A.; Parfenov, V.N.; Sustmann, C.; Grosschedl, R.; Tomilin, A. PIAS proteins as repressors of Oct4 function. J. Mol. Biol. 2007, 374, 1200-1212. [CrossRef]

119. Xu, D.; Qu, C. Protein tyrosine phosphatases in the JAK/STAT pathway. Front. Biosci. 2008, 13, 4925-4932. [CrossRef] [PubMed]

120. Latanya, S.M.; Harshani, L.R.; Said, S.M.J.; Nicholas, L.J.; Wu, J. Targeting Protein Tyrosine Phosphatases for Anticancer Drug Discovery. Curr. Pharm. Des. 2010, 16, 1843-1862.

121. Heather, B.; Dechert, U.; Jirik, F.; Schrader, J.W.; Welham, M.J. SHP1 and SHP2 Protein-tyrosine Phosphatases Associate with $\beta \mathrm{c}$ after Interleukin-3-induced Receptor Tyrosine Phosphorylation. J. Biol. Chem. 1997, 272, 14470-14476.

122. Böhmer, F.; Friedrich, K. Protein tyrosine phosphatases as wardens of STAT signaling. JAKSTAT 2014, 3, e28087. [CrossRef]

123. Yoshimura, A. Negative regulation of cytokine signaling. Clin. Rev. Allergy Immunol. 2005, 28, $205-220$. [CrossRef]

124. Collins, A.S.; McCoy, C.E.; Lloyd, A.T.; O'Farrelly, C.; Stevenson, N.J. miR-19a: An Effective Regulator of SOCS3 and Enhancer of JAK-STAT Signalling. PLoS ONE 2013, 8, e69090. [CrossRef]

125. Kubo, M.; Hanada, T.; Yoshimura, A. Suppressors of cytokine signaling and immunity. Nat. Immunol. 2003, 4, 1169-1176. [CrossRef]

126. Flowers, L.O.; Johnson, H.M.; Mujtaba, M.G.; Ellis, M.R.; Haider, S.M.I.; Subramaniam, P.S. Characterization of a Peptide Inhibitor of Janus Kinase 2 That Mimics Suppressor of Cytokine Signaling 1 Function. J. Immunol. 2004, 172, 7510-7518. [CrossRef]

127. Waiboci, L.W.; Ahmed, C.M.; Mujtaba, M.G.; Flowers, L.O.; Martin, J.P.; Haider, M.I.; Johnson, H.M. Both the Suppressor of Cytokine Signaling 1 (SOCS-1) Kinase Inhibitory Region and SOCS-1 Mimetic Bind to JAK2 Autophosphorylation Site: Implications for the Development of a SOCS-1 Antagonist. J. Immunol. 2007, 178, 5058-5068. [CrossRef]

128. Kershaw, N.J.; Murphy, J.M.; Lucet, I.S.; Nicola, N.A.; Babon, J.J. Regulation of Janus kinases by SOCS proteins. Biochem. Soc. Trans. 2013, 41, 1042-1047. [CrossRef]

129. Kimura, A.; Tetsuji, N.; Tatsushi, M.; Osamu, T.; Shizuo, A.; Ichiro, K.; Tadamitsu, K. Suppressor of cytokine signaling-1 selectively inhibits LPS-induced IL-6 production by regulating JAK-STAT. Blood 2004, 102, 17089-17094. [CrossRef]

130. Khan, M.Z.; Zhang, Z.; Liu, L.; Wang, D.; Mi, S.; Liu, X.; Liu, G.; Guo, G.; Li, X.; Wang, Y.; et al. Folic acid supplementation regulates key immunity-associated genes and pathways during the periparturient period in dairy cows. Asian Australas. J. Anim. Sci. 2019, 33, 1507-1519. [CrossRef]

131. Yasukawa, H.; Ohishi, M.; Mori, H.; Murakami, M.; Chinen, T.; Aki, D.; Hanada, T.; Takeda, K.; Akira, S.; Hoshijima, M.; et al. IL-6 induces an anti-inflammatory response in the absence of SOCS3 in macrophages. Nat. Immunol. 2003, 4, 551-556. [CrossRef]

132. Fang, L.; Hou, Y.; An, J.; Li, B.; Song, M.; Wang, X.; Sørensen, P.; Dong, Y.; Liu, C.; Wang, Y.; et al. Genome-wide transcriptional and post-transcriptional regulation of innate immune and defense responses of bovine mammary gland to Staphylococcus aureus. Front. Cell. Infect. Microbiol. 2016, 6. [CrossRef]

133. Huang, Y.; Zhao, F.; Luo, C.; Zhang, X.; Yu, S.; Sun, Z.; Li, Z.; Li, Q.; Gao, X. SOCS3-Mediated Blockade Reveals Major Contribution of JAK2/STAT5 Signaling Pathway to Lactation and Proliferation of Dairy Cow Mammary Epithelial Cells in Vitro. Molecules 2013, 18, 12987-13002. [CrossRef] 
134. Dif, F.; Saunier, E.; Demeneix, B.; Kelly, P.A.; Edery, M. Cytokine-inducible SH2-containing protein suppresses PRL signaling by binding the PRL receptor. Endocrinology 2001, 142, 5286-5293. [CrossRef]

135. Rupp, R.; Senin, P.; Sarry, J.; Allain, C.; Tasca, C.; Ligat, L. A Point Mutation in Suppressor of Cytokine Signalling 2 (Socs2) Increases the Susceptibility to Inflammation of the Mammary Gland while Associated with Higher Body Weight and Size and Higher Milk Production in a Sheep Model. PLoS Genet. 2015, 11, e1005629. [CrossRef]

Publisher's Note: MDPI stays neutral with regard to jurisdictional claims in published maps and institutional affiliations.

(C) 2020 by the authors. Licensee MDPI, Basel, Switzerland. This article is an open access article distributed under the terms and conditions of the Creative Commons Attribution (CC BY) license (http://creativecommons.org/licenses/by/4.0/). 